\title{
1
}

\section{Introduction: Citizen Organisations, Transnational Solidarity and Collective Learning in Europe}

\section{Christian Lahusen, Ulrike Zschache, and Maria Kousis}

\section{Introduction}

Citizen groups and organisations are engaged in acts of solidarity throughout Europe during times of welfare retrenchment and austerity, economic and governance crises. Such acts appear to have increasingly embodied a transnational dimension (Smith 1997; Davies 2014). The field of initiatives and activities is as diverse as the range of problems, hardships and deprivations they address. Their solidarity activities range from service provision and social economy projects to public information, political

C. Lahusen $(\bowtie) \bullet U$. Zschache

Department of Social Sciences, University of Siegen, Siegen,

Nordrhein-Westfalen, Germany

e-mail: lahusen@soziologie.uni-siegen.de;

zschache@sozialwissenschaften.uni-siegen.de

M. Kousis

University of Crete Research Center for the Humanities, the Social and Education Sciences (UCRC), Rethymno, Greece e-mail: kousis.m@uoc.gr

C. Lahusen et al. (eds.), Transnational Solidarity in Times of Crises, Palgrave Studies in European Political Sociology, https://doi.org/10.1007/978-3-030-49659-3_1 
advocacy and street protests. Organisations involved in transnational solidarity have roots as far back as the early 1900s, while depending on national contexts, many others have just been established under neoliberal restructuring and crises of the past decade (Kousis et al. 2020). Also, their forms of organisation diverge considerably when comparing highly formalised entities, such as philanthropic organisations, charities, welfare associations or workers' unions with informal citizen groups and initiatives, like barter clubs and networks, time banks, cooperatives, citizens' self-help groups or solidarity networks covering urgent needs.

All of these groups and organisations share one common trait. They are part of a highly dynamic field of solidarity initiatives responding to ongoing societal challenges. This dynamism seems to be driven by two elements. On the one hand, solidarity groups tend to react to upcoming and changing societal problems and grievances. This is particularly true when examining the situation in Europe from the time of the global financial crisis (2008) and the so-called refugee crisis of 2015, both of which accentuated the importance and growth of solidarity organisations and their activities (Ataç et al. 2016; Lahusen et al. 2018). Many of these groups respond to mushrooming grievances and needs by providing services and goods, engaging in advocacy and increasing public pressure on state authorities. On the other hand, civic groups and organisations are also involved in processes of collective learning that lead to the identification of unmet problems and risks, new types of relations with beneficiaries/ target groups, the promotion of new missions and values and the propagation of new instruments and solutions. Solidarity is a principle that emphasises obvious and hidden forms of injustice and discrimination, engages in the empowerment of deprived fringes of the population, propagates the expansion of political and social rights and calls for new forms of conviviality and societal integration. More often than not, these collective deliberations and learning processes are highly contentious, given that transnationally oriented solidarity groups and organisations have differing priorities and missions, and also diverge in their convictions and values.

Previous research has been interested in the arena of civic solidarity, particularly with regard to specific issue fields. Works on disability-related solidarity organisations provide insights into the national level and the global south (Soldatic and Grech 2014; Hande and Kelly 2015), while scholars interested in unemployment and labour solidarity issues have 
dealt with organisations at the global, European and national levels (McCallum 2013; Scipes 2016; Baglioni and Giugni 2014) while disregarding transnational solidarity at the local and grassroots level. New work based on random samples of transnational solidarity organisations (TSOs) in eight European countries offers findings based on quantitative data (Lahusen et al. 2018; Kousis et al. 2018; Kousis et al. 2020). However, there is a noticeable lack of qualitative cross-national studies on smaller scale, locally based, transnational solidarity organisations active during the recent crises period, and their crises experiences, the ways in which they perceive constraints and risks, and describe and assess the potentials for transnational solidarity work.

This book is devoted to the analysis of this field, based on fresh data about existing citizen groups and organisations in Denmark, France, Germany, Greece, Italy, Poland, Switzerland and the UK, across the fields of disability, immigration and unemployment. The aim is to engage in indepth analyses that allow us to better understand the patterns and dynamics of service and political oriented transnational solidarity. The book will centre on the local, grassroots level, because this is where pressing needs and grievances make themselves felt (Kousis et al. 2020), where citizen-led solidarity activities materialise and where learning processes evolve in a tangible manner. As will be explained in more depth later, the selection of countries and issue fields was motivated by our aim to grasp the diversity of experiences of transnational solidarity organisations. The findings mirror the realities within different countries and organisational fields during hard times, allowing us to identify similarities and differences in the way transnationally oriented solidarity groups and organisations respond to societal challenges and draw lessons from their engagement.

The contributions to this book allow for a truly comparative analysis, because they rely on the same conceptual and methodological framework that has produced eight national datasets in the context of Work Package 2 of the European research project, TransSOL (Lahusen 2020). ${ }^{1}$ At least

\footnotetext{
${ }^{1}$ Results presented in this volume have been obtained from Work Package 2 of the TransSOL project ("European paths to transnational solidarity at times of crisis: Conditions, forms, role models and policy responses"). This project has received funding from the European Union's Horizon 2020 research and innovation programme under grant agreement No. 649435. http://transsol.eu. See specifically Work Package 2 Integrated Report, Part III (pp. 120-277 and 336-341) at https://blogs. uni-siegen.de/transsol/files/2016/12/Integrated-Report-on-Reflective-Forms-of-Transnational-
} 
30 in-depth and non-standardised, qualitative interviews, 10 in each field, were carried out with representatives and activists of transnational solidarity organisations (conforming to the same criteria of selection) in each country, offering a comparable base of 247 interviews. On these grounds, the book wishes to provide new insights into at least four areas. First, the contributions to this volume are geared to painting a rich picture of locally embedded transnationally oriented civic solidarity in national contexts differentially experiencing the various crises affecting Europe, primarily by highlighting their perceptions of their missions, activities and forms of collaboration. Second, the chapters aim to provide in-depth analyses that allow us to understand the main patterns guiding such solidarity action by citizen groups and organisations across the three issue fields and the way these patterns are related to societal contexts undergoing welfare retrenchment and crises-related policies. Third, authors highlight the ways in which citizen groups and smaller-scale transnational solidarity organisations at the grassroots level engage in collective learning and in adapting their work to these changing circumstances. Finally, the contributions also identify the extent to which these organisations are enmeshed in transnational networks of cooperation and support, allowing us to reflect on the extent to which they are equipped to meet the challenges of European solidarity.

\section{Organised Citizens and Transnational Solidarity: Mapping the Field Conceptually and Empirically}

Solidarity is an area of continuous concern for social scientists, as it is one of the basic components of sociability, social integration and societal cohesion. Research has been interested in various manifestations of solidarity, ranging from forms of social solidarity between individuals that emerge from the informal webs of social relations at the micro level (Bell and Boat 1957; Komter 2005) to institutionalised forms of solidarity

Solidarity.pdf. The diligence, enthusiasm and work of all the teams involved in Work Package 2 are gratefully acknowledged. 
at the macro level linked to the welfare state and its policies of redistribution (Baldwin 1990; Arts and Gelissen 2001). Organised forms of citizen solidarity are located between these levels, because they reside in coordinated collective actions and thus transcend the individual level, while being tied back to specific groups of citizens, and thus placed below the level of welfare institutions and public policies. These forms of collective action have been at the centre of attention of various research strands with intersecting debates that have addressed topics such as social capital (Putnam 2000; van Oorschot et al. 2006), volunteering (Anheier and Salamon 1999; Gil-Lacruz et al. 2017), the non-profit or third sector (Evers 1995; Salamon and Sokolowski 2016; Kousis 2017), civil societies (Hall 1995; Smismans 2006) and social movements (McAdam et al. 1996; della Porta and Caiani 2009; Kousis et al. 2018). In particular, the latter three debates provide important insights for our study, because they focus on organised collective action, organisational actors, fields or sectors. Although they have not always addressed their research area in terms of solidarity during hard times, most of their findings are immediately relevant for a better understanding of the specificities of organised forms of solidarity as collective action.

We define solidarity as a disposition and practice of help or support towards others (Stjerno 2012: 88; also Bayertz 1999; de Deken et al. 2006; Smith and Sorrell 2014). More specifically, solidarity transcends the unilateral orientation of concepts such as care, empathy or altruism (Passy 2001), even though it shares some of the same features. In fact, solidarity might be described empirically along different types of orientations and relations: top-down relations of unilateral help refer to philanthropic values or altruistic motives in support of others; bottom-up or horizontal relations of support are governed by principles of reciprocity and mutualism (Uba and Kousis 2018; Kousis et al. 2020; Zschache et al. 2020). However, to grasp the specificity of solidarity, we have to understand the peculiar exigency it imposes, given that it is linked to reciprocal expectations and practices between people expressing sameness, togetherness and inclusiveness, which means that solidarity assumes the existence of (imagined) reference groups with some sort of mutual responsibilities. Solidarity might be restricted to national communities (particularistic solidarity), thus excluding outsiders (for instance, migrants), but more 
often than not, solidarity implies a wider community of equals (such as humankind-universalistic solidarity), thus eliminating the distinction between insiders and outsiders. In all cases, solidarity presupposes a conception of shared rights, responsibilities and obligations (Lahusen 2020) to be applied to particular and/or universal groups.

Solidarity groups and organisations by non-state/non-corporate actors are a specific manifestation of these dispositions and practices of support to others (TransSOL 2016; Kousis et al. 2018). They mobilise and organise a certain group of people (members, followers, beneficiaries), employ joint forms of actions, delimit a shared collective identity and rally for a shared mission. In this sense, organised forms of solidarity are the means to stabilise collective action of (unilateral or mutual) support across time and to expand its reach beyond the immediate area of activities of individuals. Organisation (as a resource, an activity and an entity) is an important means of mobilising, coordinating and perpetuating citizens' solidarity actions by providing incentives, action repertoires, facilities, norms and identities. This seems to be particularly important in a transnational context like the European Union, where citizens organise in order to support citizens from other countries and confront shared grievances emanating from welfare retrenchment, austerity and crises which European societies face jointly (Balme and Chabanet 2008; della Porta and Caiani 2009; Baglioni and Giugni 2014; Verschraegen and Vandevoordt 2019; Fominaya and Feenstra 2019; Monforte 2014; Zamponi 2019). In order to empirically map and analyse this field, we will thus centre on formal or informal (non-state) groups or organisations that carry out solidarity practices with beneficiaries or participants and raise claims on the improvement of their economic and social well-being and the enforcement of existing rights. This field of groups and organisations involves more formal entities, such as welfare associations, union groups and religious organisations. Since our focus is on the local level, however, the range of organisations needs to be expanded towards a wider range of informal groupings, including, for instance, barter clubs and networks covering urgent/basic needs, credit unions, ethical banks, time banks, alternative social currency, cooperatives, self-help groups and social enterprises (Kousis et al. 2018; Lahusen et al. 2018). The specific trait we are particularly interested in is the transnational scope of these 
groups and organisations which materialises in goals and missions, activities and beneficiaries, participants or users (see section Rationale for Country and Field Selection below for details, also TransSOL 2016; Kousis et al. 2018; Kousis et al. 2020).

Research on non-profit sectors, civil societies and social movements helps to better understand the dynamics of organised forms of citizen solidarity at the grassroots level, in particular, because it sensitises us to the fact that solidarity involves civic and political components at the same time. In regard to the civic component of solidarity, we can refer to scholarly writing about the non-profit sector and organised civil society, which has taken a closer look at a wide range of groups and organisations that follow a philanthropic mission, aiming to meet the needs of fellow citizens and/or non-nationals. This approach mirrors an understanding of solidarity that tends to privilege compassion, altruism and care (Skitka and Tetlock 1993; Schroeder et al. 1995; van Oorschot 2000). Action repertoires lean strongly towards the provision of help and support, primarily in terms of services and goods (for instance, food, clothing, shelter, medical treatments, financial assistance, education or training). These action repertoires propel the formalisation and professionalisation of the organisations and their members, given that effectivity and efficiency are important reference points when assessing the performance of solidarity work in terms of service provision. These developments have led to the formation of highly populated non-profit sectors with an extended labour market of paid staff and complementary constituencies of members, volunteers and followers (Anheier and Salamon 1999; Kendall 2009; GilLacruz et al. 2017).

In regard to the political component of solidarity, we can refer to research on social movements, because these studies have highlighted the advocatory element of collective actions. This activism is relevant for a study of political solidarity, because these citizen groups and organisations denounce injustice, discrimination and oppression suffered by specific groups or communities, because they speak out on behalf of their rights and engage in activities geared to improving their situation (Scholz 2008; Bayertz 1999: 16). These groups might be engaged in the delivery of services and goods, as well, but the advocatory element is a more dominant part of their mission and activism, given that they rally publicly in 
order to pressure governments, public administrations, political and economic elites and other stakeholders to revise public policies, implement programmes and step up remedial actions. Action repertoires make use of advocatory activities such as public awareness campaigns, consumer boycotts or buycotts, lobbying activities and various and sundry forms of political protests (della Porta and Caiani 2009; Giugni and Grasso 2015). These political orientations and action repertoires are often associated with less formalised and professionalised organisations, given that mobilisation and empowerment are centre stage. In fact, the advocatory mission of these groups builds on the mobilisation of public support and the extended participation of citizens, and this seems to privilege organisational formats that provide more access, incentives and expressive means of participation. Additionally, organisational matters, less linked to questions of efficiency and effectiveness, are more oriented towards issues of legitimacy, thus favouring participatory grassroots structures. Political solidarity thus materialises more often in informal citizens groups, decentralised networks, joint activities organised by broad alliances and in loosely coordinated protest campaigns (Klandermans 1993; della Porta and Tarrow 2005).

The civic and political components of solidarity also coexist. In fact, both components should be conceived of as endpoints of a continuum of potential solidarity orientations, action repertoires and organisational structures. The chapters of this book will provide rich evidence about the variability of expressions of organised transnational solidarity. While many citizen groups and organisations conform to the descriptions of the civic and political type of solidarity respectively, there are also numerous examples of organisations that are committed to both, civic and political solidarity, philanthropic and advocatory action repertoires in the public sphere. These hybrid forms of collective action have been analysed in previous studies (Minkoff 2002; Baglioni and Giugni 2014, Kousis and Paschou 2017; Kousis et al. 2018; Uba and Kousis 2018; Fernández G. G. et al. 2020; Zschache et al. 2020), evidencing the fact that citizens' engagement is more often than not a product of mixed contextual exigencies and learning processes, which call for a combination of service provision and political advocacy as necessary tools to combat social problems and deprivations successfully (see also Kousis et al. 2020; Fernández G. G. et al. 2020). 


\section{Organised Transnational Solidarity in Context: External and Internal Drivers}

The observations outlined above demonstrate that solidarity engagement varies across time and space. These variations are important, because they raise our awareness of the fact that varying levels and forms of transnational solidarity are not simply given. They are patterned by a number of factors that have been at the centre of numerous studies. Research in the field of non-profit sectors, civil societies and social movements have been interested in identifying conditions, circumstances and drivers of civic engagement and collective action. In this regard, they have highlighted a number of external and internal factors that either are related to the societal context or are part of the internal dynamics of collective action.

\section{External Factors: Do Welfare Retrenchment, Austerity and Crises Matter?}

The first set of factors refers to the relation between solidarity organisations and their socio-economic and political environment. An issue that has been widely discussed is the explanatory power of external problems, grievances and deprivations affected by "environmental factors" (McAdam et al. 1996). Is the engagement of citizens and the work of citizen initiatives and organisations a direct reaction to increased needs among the general population and/or specific groups? This issue is of particular relevance to our study, given that our fieldwork was conducted in times of accelerating social problems, welfare retrenchment, austerity and multiple crises. The latter affected substantial number of people, led to considerable commotions of the established order and called the problem-solving capacity of public institutions (e.g., the nation-states, the European Union and the financial institutions) into question. Citizens and citizen groups stepped up their activities in order to confront social degradations in areas confronting a pressing need. This reading of the situation is indicative of organised solidarity being strongly driven by contextual factors and developments.

This book will provide empirical evidence of this responsiveness by taking a closer look at smaller scale, locally oriented TSOs, albeit pushing 
for a more nuanced analysis that allows us to conform to lessons drawn from previous research. According to these lessons, it is unlikely that objective deprivations automatically translate to collective actions by citizens. Research on collective action and social movements, for instance, has argued that objective deprivations and grievances might be a necessary, but not a sufficient condition for protest action. In particular, they stress that the emergence of social movements requires the availability of resources and the capacity to organise (McCarthy and Zald 1977). Additionally, deprivations need to be perceived as unequal, which means that feelings of relative deprivation (such as between past and present situations, between one's own and relevant reference groups) are the more relevant factor to be taken into consideration (Gurr 1973; Dubé and Guimond 1986). Moreover, recent studies show that solidarity groups are also motivated to struggle against deprivations and grievances experienced by others (for instance, refugees, the jobless and disabled people), thus highlighting the importance of political visions, values and shared identities (Zschache et al. 2020). Finally, current research on the waves of protest mobilisation in times of the economic crisis highlights that socioeconomic deprivations are closely associated with political transformations, in particular with the accelerating public debt, the retrenchment of the welfare state, the policies of austerity and the decreasing legitimacy of the established political institutions (see Baglioni and Giugni 2014; Ancelovici et al. 2016; Verschraegen and Vandevoordt 2019; Fominaya and Feenstra 2019; Monforte 2014; Zamponi 2019; Kousis et al. 2020). Protest movements throughout Europe have been particularly concerned about the way public authorities have dealt with the Eurozone and refugee governance crisis, thus adding a strong political component to their discourse and activities (della Porta 2015; Kriesi 2016; della Porta 2018).

In this sense, we seem to be witnessing a growing politicisation of solidarity work. Citizen groups converge on the experience of politically induced deteriorations in all fields of activity. Service-oriented organisations lament reduced public spending as much as advocacy groups not dependent on state funds are alarmed by the decreasing responsiveness of the state. As a consequence, the analysis of organised transnational solidarity has to look carefully at the way in which engaged citizens and 
activists read and interpret the socio-economic and political nature of the problems they address, and how these readings translate to collective action.

\section{Internal Factors: Do the Activists' Experiences, Organisational Structures and Collaborations Matter?}

The qualitative approach of this book will be revelatory, because it sensitises us to the fact that citizen groups and organisations react to the needs and grievances within their social environment on the basis of their own experiences and understandings. This implies divergences and contentions about the accurate definition of what the main problems and challenges, the correct route of action and the preferred solutions are. The qualitative approach provides authentic insights into the experiences of these groups and organisations, and into the patterns and dynamics guiding their collective actions. Based on their accounts, we were able to identify two topics that seem to pattern how solidarity is organised: action repertoires and cooperation networks.

The organisation of citizens' solidarity entails choices about the type of activities they are asked to support. In fact, citizen groups delineate not only the issues, problems and beneficiaries they address but also the type of activities members or supporters (paid staff, paycheck members, volunteers, beneficiaries, etc.) should do on their behalf. The range of activities is considerable when considering the variety of citizen groups involved. Solidarity groups in the area of disabilities, unemployment or immigration are engaged in different activities when providing assistance and goods, advocating for policy reforms or conducting public communication campaigns, because they address issue-specific grievances and beneficiary-related needs. However, the variability of activities has its limits, given that citizen groups do not randomly make choices. On the contrary, research agrees that initiatives and organisations in the nonprofit and social movement sector adopt action repertoires in a purposeful, rational and even strategic manner (Rucht 1990; Pope et al. 2018). Their choices are governed by different rationales, which are related to organisational missions and values. In instrumental terms, action 
repertoires are adopted and adapted to conform to effectivity criteria. This applies to service-oriented organisations that aim to meet needs and ameliorate deprivations successfully, as much as it applies to advocacy groups that wish to influence ongoing public debates and shape public policies effectively. In expressive terms, action repertoires are moulded so they mirror and convey the underlying collective identities and values of the organisations involved, thus very often implying performative, evocative or creative means of action (Derman 2017).

Due to these instrumental and expressive rationales, citizen groups and organisations privilege some practices while discarding others. Before this backdrop, analysts of social movements have demonstrated that protest groups develop a set of practices (such as street demonstrations, sit-ins, blockades and boycotts) that they share with others, thus forming and promoting specific action repertoires (Tilly 1984) that are widely used by different groups and might also be diffused across time and space (Traugott 1995; Chabot 2000). These action repertoires are exposed to constant change, given that citizen groups and organisations adapt them to new needs, circumstances, objectives and ideas. This is not only a lesson in historical analysis (Traugott 1995; Tilly 2004) but also a finding of current research, which stresses the impact of technological changes on action repertoires. In this context, the internet and social media have strongly altered the way citizen groups act within the public sphere (Cammaerts 2015; van Laer and van Aelst 2010), even though it is important to remember that technology is not the only factor impinging on activities. In fact, historical analyses have insisted on the observation that action repertoires are also strongly affected by the organisational and political contexts within which citizen groups operate (Tilly 2004: 105). Action repertoires are moulded by the opportunities and constraints provided by the nation-state, as corroborated by the study of protest groups (Tarrow 1996; Wada 2016). This observation also applies to non-profit organisations (Powell and DiMaggio 1992; Pope et al. 2018), given that non-protest-oriented solidarity groups tend to adapt to the needs, funding opportunities and standard operating procedures established by the state (Minkoff and Powell 2006), meaning that organisational fields tend to adopt similar practices and streamline their activism accordingly. 
For instance, it can be assumed that action repertoires might diverge between organisations active in the fields of disabilities, unemployment and immigration. However, action repertoires should also be exposed to processes of change. As aforementioned, solidarity has been politicised, meaning that TSOs might expand their range of activities towards advocacy and protest. Additionally, solidarity groups and organisations are involved in wider webs of cooperation, which nurture learning processes and make space for social innovations. Solidarity work involves elements of collective learning, where activists evaluate the effectiveness and persuasiveness of established activities and where they experiment with new means and practices of liaising with their beneficiaries, designing services and modelling their advocacy work. While these activities might not in themselves be completely new, there is an innovative element in the way they adopt and adapt them to upcoming needs, their standard repertoires of action and the discourse they share with others in the field.

Transnational solidarity practices do not emanate only from the agency of individual groups and organisations but are in most cases tied back to wider networks of collaboration. In fact, studies of the non-profit sector, civil society and social movements all underscore the fact that these groups are part of complex organisational fields. Even though relations of competition might arise between them (MacIndoe 2014; Soule and King 2008), there is supporting evidence that organisations regularly engage in diverse activities of cooperation (Zald and McCarthy 1979; Hathaway and Meyer 1994), even under conditions of fractionalisation, conflict and competition. These loose networks of cooperation are the backbone of what research calls social movements and/or civil societies. They are of particular importance because they augment the scope of activities of each individual group and organisation, for instance, with regard to the mobilisation of broad popular support (Klandermans and Oegema 1987) and the organisation of effective change activities (Soule and King 2008).

The pervasiveness of cooperation is particularly true at the grassroots level, where opportunities and circumstances seem to increase the likelihood of such collaborations, given overlapping memberships and beneficiaries, recurrent contacts and collaborations in regard to local projects and/or the shared involvement in consultative bodies (Baglioni and Giugni 2014). However, these networks of collaboration are also true for 
the national and international levels of activity. Civil society and social movement organisations have opted individually for a "scale shift" (Tarrow and McAdam 2005), according to which they move their centre of operation from the local to the national and supranational levels. In regard to Europe, we have witnessed the emergence of a supranational field of European organisations that have expanded their scope of activities simultaneously to a Pan-European area of operation (Smismans 2006; Balme and Chabanet 2008), and the same is true for the global arenas (Smith 1997; Smith and Johnston 2002). These "scale shifts" have also impacted at the grassroots level, because many of these national and international organisations maintain local branches, contacts and collaborations, thus immersing local spaces of citizens' engagement into transnational networks of activities (della Porta and Caiani 2009). At the same time, these extended networks have encouraged local groups and organisations to expand the range of their own contacts and activities across borders, by engaging in cross-border grassroots activism (Lahusen et al. 2018).

Cooperation is not only a recurrent feature in the field of civil society and social movements; it also shapes the activities and structures of solidarity groups. Collaboration seems less important in regard to service provision but more so when advocacy work and protest actions are at stake. The effectiveness of advocacy benefits greatly from it, and this is a reason why civil society organisations organise their work along different modes of collaboration (Diani 2018), for instance, by engaging in structured coalitions between the organisations and/or favouring a looser cooperation of individual activists in regard to specific events. However, collaborations are not only a pragmatic necessity to increase the reach and effectivity of one's own work but also a programmatic goal enshrined in the notion of solidarity: Solidarity means maintaining contact with other groups, engaging in mutual support activities and promoting common goals and identities. Citizen groups and organisations are thus more often than not involved in wider networks of cooperation, at both local and transnational levels. As argued elsewhere (Lahusen 2020), the intensity of cooperation and the forms of collaboration diverge considerably. On one side of the spectrum, transnational cooperation can be highly formalised and centralised in the form of international organisations with 
legs in various countries, regions and/or cities; also international umbrellas, federations or platforms would belong to this group of strong transnationalism. These organisations would involve their members in organised forms of transnational service-delivery and advocacy. The organisational fields at stake in this book, however, seem to be placed at the other end of the spectrum. Here, we should expect few formalised networks of local groups engaging in specific activities for specific purposes and using existing means of communication to coordinate their various activities autonomously. Social movement studies have provided ample evidence for this form of loosely coupled forms of (transnational) collective action, emerging from diffusion cycles and mobilisation waves (della Porta and Tarrow 2005). The latter are tied to specific issues, occasions and locations, but they build on wider networks that seem to be particularly strong in circulating news, ideas, claims and practices across borders. In these cases, solidarity work is based on soft forms of transnationalisation that seem to be shorter lived, but have the potential for instigating vivid waves of mobilisation.

\section{Approach and Structure of the Book}

This book is devoted to the analysis of transnational solidarity groups in eight European countries. Its scope is strongly shaped by the analytic framework and the methodological choices which guided the qualitative fieldwork and data analysis. Before engaging in a brief presentation of the various chapters and its main findings, it is necessary to address the common research design and its main criteria.

\section{Rationale for Country and Field Selection}

Data and findings of this book stem from an international research project (TransSOL) funded by the European Union (Lahusen 2020). The project's main objective was to map and analyse European solidarity in various European countries at different levels of action: at the micro level through an individual survey (Lahusen and Grasso 2018); at the meso 
level through a standardised website content analysis (Kousis et al. 2020), organisational surveys and a series of in-depth interviews; and at the macro level through a comparative study of laws and public policies (Federico and Lahusen 2018) and media content analysis (Cinalli et al. 2021). While the organisational surveys (TransSOL 2016) aimed at generating standardised datasets to describe and analyse the structures of the organisational fields in comparative terms across countries and issue fields, qualitative interviews were conducted to grasp the lived experiences of solidarity activism at the grassroots level and thus reach a more in-depth understanding of contextual circumstances, action strategies and networking structures.

The methodological approach was comparative, given that the project aimed at systematically mapping and analysing solidarity during times of welfare retrenchment and crises in eight countries (Denmark, France, Germany, Greece, Italy, Poland, Switzerland and the UK) and three issue fields (disabilities, unemployment and immigration). The choice of countries was driven by three criteria: different exposure to societal grievances in the wake of economic and financial crises since 2008; different levels and forms of institutionalised solidarity in the form of welfare state policies; and different levels of citizen participation as a measure of differing levels of the likelihood of citizens to engage in solidarity actions towards target groups. The sample ranges from countries such as Greece, with its less-developed welfare state, strong exposure to the crisis, shorter history of civic participation, but more contentious social movements landscape, to countries like Germany, Denmark and Switzerland, with their strongly developed welfare state, lower exposure to the global economic and financial crisis and long traditions of civic engagement, as well as a number of countries with unequal combinations of these criteria (Italy, France, Poland and the UK). The so-called refugee crisis emerged as a significant field of contentions after the start of the project but was proactively integrated into the research design, thus deepening the contextual differences between countries affected by multiple crises and challenges (Greece and Italy), individual ones (Germany and Switzerland) and countries with a more limited (Denmark, France, and the UK) or indirect exposure (Poland). 
The three issue fields were selected in order to grasp what previous research had identified in terms of conditional support (Lahusen 2020). In fact, solidarity is a positively connoted value that might not necessarily arouse strong opposition when addressed in terms of general dispositions and practices. Solidarity, however, becomes conditional once we leave the abstract level of principles and move to specific target groups. In this vein, the TransSOL project followed the idea of contentiousness, assuming that solidarity might mobilise as much support as it arouses opposition, once focused on more specific targets. The choice of issue fields was motivated by previous insights into the "deservingness" of various social groups. According to public opinion polls, the elderly and disabled people are generally considered to be the most deserving, followed by unemployed people, with immigrants seen as the least deserving (van Oorschot et al. 2006: 23). Deservingness is an issue to take into consideration, because citizens might limit solidarity to the more deserving targets while making their support more conditional when groups are concerned that seem to be less deserving.

Overall, our selection of countries and issue fields was motivated by the aim to empirically map the arena of civic and political solidarity in its different expressions and manifestations. In regard to our dependent variable (civic solidarity), we opted for identical issue fields across the eight countries, an identical sample of interviewed organisations and joint guidelines to generate comparable data. In regard to contexts, we opted to include very different issue fields and countries in order to empirically map differing levels of solidarity engagement, identify similarities across countries and issue fields and engage in explanatory analyses that relate differing contexts (countries and issue fields) to diverging levels and forms of solidarity.

The analyses of this book are based on a common and rigorous research framework with in-depth interviews drawn from 247 representatives of TSOs in all participating countries across the three fields. Each national team conducted 30 interviews in their own country (with the exception of Germany, with 37) following guidelines that defined the key interviewees, the number of interviews for each alternative structure and the content of the interviews. Each interview partner signed an official consent letter for the use of the data. Based on hub-website retrieval and 
Action Organisation Analysis using the organisational websites of the Trans SOL project (Kousis et al. 2018), we extracted a sub-sample of groups and organisations to be interviewed. Organisations/groups were prioritised as follows: (1) informal groups/organisations (e.g., grassroots solidarity initiatives, information platforms and networks, social economy enterprises, cooperatives and unions); (2) non-governmental organisations (NGOs) without paid staff or with very few staff (such as volunteer associations, non-profit professional and formal organisations); (3) local NGOs with few staff; (4) protest-oriented groups (for instance, social protest groups and neighbourhood assemblies); and (5) transnational social movement groups (see TransSOL 2016: 122-123). Teams were asked to assure enough variance in the TSOs to be interviewed: "charity/practical help/service-oriented" and "protest/social movement/ policy-oriented". Given our focus on transnational solidarity, only groups which complied with at least one of the following nine criteria were included in the organisational mapping and the subsequent interview sample (see TransSOL 2016: 32):

1. Organisers with at least one organiser from another country, or supranational agency

2. Actions synchronised/coordinated in at least one other country

3. Beneficiaries with at least one beneficiary group from another country

4. Participants/Supporters with at least one Participating/Supporting Group from another country

5. Partners/Collaborating Groups with at least one from another country

6. Sponsors, with at least one from another country or a supranational agency (for instance, European Regional Development Fund and European Social Fund)

7. Frames with cross-national reference/s

8. Volunteers with at least one volunteer group from another country

9. Spatial at least across two countries (at the local, regional or national levels)

The guidelines were aimed to guarantee as much comparability as possible, without decreasing the authenticity and richness of each interview. During the development of the guidelines, we aimed to identify topics 
that were relevant in all countries. Guidelines raised topics rather than asking specific questions in order to leave interviewees as much room as possible to define the relevant questions for themselves (Chamaz 2000; Roulston 2014). The guidelines were pretested and adapted in various rounds. Overall, the interview guidelines focused on five thematic groups: (1) information about the group/organisation and the interviewee's level/ depth of involvement with the given group/organisation; (2) target groups and activities of solidarity, including social innovations; (3) the field of activism (within and beyond country borders), inter-organisational links (within and beyond country borders), degrees of institutionalisation and public support; (4) discussion of existing laws, policies or court decisions, and related demands; and (5) the societal context, including potential references to various crises.

Based on the same research design (sampling criteria, guidelines and interview instructions), personal interviews were carried out from early summer to late autumn of 2016 in each country, with representatives/ participants from TSOs conforming to the aforementioned sampling criteria. The analysis of the interviews focused on each of the five thematic blocks, summarising and paraphrasing the main findings across issue fields for each of the eight countries (Roulston 2014), following precepts of inductive coding stipulated by Grounded Theory (Strauss and Corbin 1990; Chamaz 2000).

\section{Overview of the Book}

The book is devoted to citizen groups and organisations that are engaged in transnational solidarity work under quite diverse socio-economic and political contexts. Each chapter provides insights into the specific way TSOs experience current challenges and problems, which activities they conduct in regard to the various beneficiaries and participants under study and how they portray collaborations. Owing to the importance of the diverging socio-economic and political contexts, the analyses start with the two countries most severely hit by the Eurozone and the socalled refugee crisis (Greece and Italy) and the country most receptive to the dramatic inflow of refugees (Germany), moving only then to those 
countries that were less strongly and most often indirectly affected by the dual crisis. In these countries, the experience of policy-driven aggravations stemming from austerity measures, welfare retrenchments and immigration restrictions is a much more notable reference point for grassroots solidarity work, even though this element is also apparent among the Mediterranean countries, as it deepened the effect of the crisis on those vulnerable groups that solidarity groups were committed to assisting.

The first two chapters highlight the dramatic effects the Eurozone and the so-called refugee crises have had on local solidarity work. Kostas Kanellopoulos et al. devote themselves to the Greek experience and show that the dual crisis has exposed the population to dramatic hardships while boosting the development of civil society. Socio-economic grievances and the deteriorating political framework led to the growth of the organisational field that has become more differentiated in terms of issues and groupings, and more politicised in its activities and discourses. As Nicola Maggini and Veronica Federico show, this experience is replicated in the Italian case. Even though solidarity groups are well established in all issue fields, they had to step up their activities substantially in reaction to the dual crisis. While differences in the fields of unemployment, disabilities and migration persist, leading to considerable fragmentation, solidarity groups tend to converge in their attempts to develop new strategies and approaches to increase the impact of their work under conditions of limited resources and opportunities. Also, the German case testifies, according to Ulrike Zschache, that citizens were able to react to upcoming immediate needs under considerable time constraints. Civic engagement is embedded in established fields of civil society organisations, which explain the considerable pace and breadth of the German welcoming culture. Of particular relevance is the dynamism unleashed by the intense mobilisation of public solidarity, given that it encouraged a shared discourse across issue fields that developed a more political and allencompassing notion of what solidarity is about.

The following case studies provide insights into a societal context less marked by dramatic commotions associated with the various crises. In these countries, organised solidarity is rather exposed to long-standing processes and/or specific moments of policy-driven aggravations affecting 
labour markets, immigration and the inclusion of disabled people in social life. Janina Petelczyc et al. demonstrate convincingly for the Polish case that solidarity groups and organisations have to work within a more hostile political environment, marked by public policies of welfare retrenchment, liberalisation of labour markets and right-wing debates of immigration control. Solidarity groups have tended to disengage from overtly political discourses while engaging in new strategies and approaches that strive to increase the range of beneficiaries and collaborations. These adaptive strategies are corroborated by Manlio Cinalli et al. for the French case. Also in this country, the dual crisis is just a momentary element within a longer-standing process of welfare retrenchment that affects citizens and civil society organisations. French solidarity groups deviate partially from the Polish, because they engage more proactively in collaborations as a means to increase capacities and effectivity. However, the focus on service delivery is complemented more forcefully by a political approach of advocacy that develops more formal and professional patterns.

The Danish, British and Swiss experiences evidence considerable transformations within the field of solidarity work, against the backdrop of socio-economic aggravations and welfare retrenchment policies. Deniz N. Duru et al. argue in regard to the Danish case that the long-standing reforms of the Danish welfare state, the more restrictive immigration policies and the impressions of the Eurozone and the so-called refugee crisis have led to a more confrontative relationship between civil society and public authorities, in what traditionally was considered to be highly cooperative forms of welfare service provision. Solidarity groups have become more political in regard to the provision of services and the defence of their social rights, thus entering into conflict with the government. This conflict is complemented by a potential dividing line within the field of solidarity groups, as Simone Baglioni et al. illustrate for the British case. Decades of privatisation and liberalisation policies, welfare retrenchment measures and a more restrictive immigration policy have not only introduced a dividing line between national politics, notably more hostile towards solidarity, and a field of grassroots solidarity groups. At the local level, there is also a potential division between grassroots organisations keeping up with transnational solidarity work and those 
groups that adapt to the public-private model of partnership-based relationships with local authorities in an attempt to sustain their operations within a context marked by austerity. Fragmentations are also a focal point of Eva Fernández G. G. et al. when addressing solidarity groups in Switzerland. Their analysis of civic organisations in the realm of immigration and labour issues shows that activities and discourses are still highly patterned along policy domains, public authorities and legal provisions, an element stressed already in the Italian case. While some solidarity groups engage in intersectional debates and activities, thus linking labour and migration issues directly, this still seems to be an exception that has trouble overcoming institutionally established fragmentations.

Overall, national case studies evidence that transnational solidarity groups and organisations operate in quite diverse socio-economic, political and institutional contexts. However, as discussed in the concluding chapter, solidarity activities and discourses exhibit a considerable number of similarities. Activists are concerned almost everywhere about growing social problems and grievances that are nurtured by either periods of dramatic crises and/or long-standing transformations of public policies. Before this backdrop, collective action is more demanding, as it has to address an increasing number of needs and demands within a more hostile environment implying cuts in funds, restrictive policy-measures and public debates stressing the conditionality of solidarity. Ulrike Zschache and Christian Lahusen argue that the activism and discourse of local TSOs tend to develop a number of commonalities. First, solidarity work has become more political in the sense of insisting more strongly on an advocatory, rights-based approach. Second, citizen groups stress the importance of collaboration as an element of increasing the effectivity of their work and as a means to conform to the exigencies of solidarity as a principle of mutual empowerment. And third, TSOs see the need to adapt to changing circumstances, engage in joint learning and promote innovations. Of particular importance is a discourse of solidarity that aims to transcend target specific groupings and engage in a more crosssectoral and integrated approach. The current crises and policy transformations tend to encourage these debates. 


\section{References}

Ancelovici, M., Dufour, P., \& Nez, H. (Eds.). (2016). Street Politics in the Age of Austerity: From the Indignados to Occupy. Amsterdam: Amsterdam University Press.

Anheier, H. K., \& Salamon, L. M. (1999). Volunteering in Cross-National Perspective: Initial Comparisons. Law and Contemporary Problems, 62(4), 43-65.

Arts, W., \& Gelissen, J. (2001). Welfare States, Solidarity and Justice Principles: Does the Type Really Matter? Acta Sociologica, 44(4), 283-299.

Ataç, I., Rygiel, K., \& Stierl, M. (2016). Introduction: The Contentious Politics of Refugee and Migrant Protest and Solidarity Movements: Remaking Citizenship from the Margins. Citizenship Studies, 20(5), 527-544.

Baglioni, S., \& Giugni, M. (Eds.). (2014). Civil Society Organizations, Unemployment, and Precarity in Europe. Between Service and Policy. Houndmills/Basingstoke: Palgrave Macmillan.

Baldwin, P. (1990). The Politics of Social Solidarity. Class Bases of the European Welfare State 1875-1975. Cambridge: Cambridge University Press.

Balme, R., \& Chabanet, D. (2008). European Governance and Democracy. Power and Protest in the EU. Lanham: Rowman \& Littlefield.

Bayertz, K. (1999). Four Uses of 'Solidarity'. In K. Bayertz K. (Ed.), Solidarity. Philosophical Studies in Contemporary Culture (pp. 3-28). Dordrecht: Springer. Bell, W., \& Boat, M. D. (1957). Urban Neighborhoods and Informal Social Relations. American Journal of Sociology, 62(4), 391-398.

Cammaerts, B. (2015). Social Media and Activism. In P. Hwa Ang \& R. Mansell (Eds.), The International Encyclopedia of Digital Communication and Society (pp. 1027-1034). Oxford: Wiley-Blackwell.

Chabot, S. (2000). Transnational Diffusion and the African American Reinvention of Gandhian Repertoire. Mobilization, 5(2), 201-216.

Chamaz, K. (2000). Grounded Theory Methodology. Objectivist and Constructivist Qualitative Methods. In N. K. Denzin \& Y. Lincoln (Eds.), Handbook of Qualitative Research (2nd ed., pp. 509-535). Thousand Oaks: Sage.

Cinalli, M., Trenz, H. J., Brändle, V., Eisele, O., \& Lahusen, C. (2021). Solidarity in the Media and Public Contention Over Refugees in Europe. London: Routledge.

Davies, T. (2014). NGOs: A New History of Transnational Civil Society. New York: Oxford University Press. 
de Deken, J., Ponds, E., \& van Riel, P. (2006). Social Solidarity. In G. L. Clard \& A. H. Munnell (Eds.), The Oxford Handbook of Pensions and Retirement Income (pp. 141-160). Oxford: Oxford University Press.

della Porta, D., \& Caiani, M. (2009). Social Movements and Europeanization.

Oxford: Oxford University Press.

della Porta, D., \& Tarrow, S. (2005). Transnational Processes and Social

Activism: An Introduction. In D. della Porta \& S. Tarrow (Eds.), Transnational

Protest and Global Activism (pp. 1-17). Lanham: Rowman \& Littlefield. della Porta, D. (2015). Social Movements in Times of Austerity: Bringing Capitalism Back into Protest Analysis. Cambridge: Polity Press.

della Porta, D. (2018). Solidarity Mobilizations in the 'Refugee Crisis'. London/ New York: Macmillan Publishers.

Derman, Ö. (2017). Stand-in as a Performative Repertoire of Action. Turkish Studies, 18(1), 182-208.

Diani, M. (2018). Unions as social movements or unions in social movements?

In J. R. Grote \& C. Wagemann (Eds.), Social Movements and Organized Labour: Passions and Interests (pp. 43-65). London: Routledge.

Dubé, L., \& Guimond, S. (1986). Relative Deprivation and Social Protest: The Personal-Group Issue. In J. M. Olson, C. P. Herman, \& M. P. Zanna (Eds.), Relative Deprivation and Social Comparison (pp. 201-216). Hillsdale: Lawrence A. Erlbaum.

Fernández G. G., E., Kousis, M., \& Lahusen, C. (2020, forthcoming). Does Organization Matter? Solidarity Approaches of Transnational Organizations across Eight European Countries. Sociological Research Online, Special Issue: Transnational Solidarity Organizations in Times of Crises: Comparative European Perspectives.

Evers, A. (1995). Part of the Welfare Mix: The Third Sector as an Intermediate Area. Voluntas, 5(2), 159-182.

Federico, V., \& Lahusen, C. (Eds.). (2018). Solidarity as a Public Virtue? Law and Public Policies in the European Union. Baden-Baden: Nomos.

Fominaya, C. F., \& Feenstra, R. A. (Eds.). (2019). Routledge Handbook of Contemporary European Social Movements: Protest in Turbulent Times. London: Routledge.

Gil-Lacruz, A. I., Marcuello, C., \& Saz-Gi, I. (2017). Individual and Social Factors in Volunteering Participation Rates in Europe. Cross-Cultural Research, 51(5), 464-490.

Giugni, M., \& Grasso, M. T. (Eds.). (2015). Austerity and Protest: Popular Contention in Times of Economic Crisis. Farnham: Ashgate. 
Gurr, T. (1973). The revolution-social-change nexus. Comparative Politics, 5, 359-392.

Hall, J. A. (Ed.). (1995). Civil Society. Theory, History, Comparison. Cambridge: Polity Press.

Hande, M. J., \& Kelly, C. (2015). Organizing Survival and Resistance in Austere Times: Shifting Disability Activism and Care Politics in Ontario, Canada. Disability \& Society, 30(7), 961-975.

Hathaway, W., \& Meyer, D. S. (1994). Competition and Cooperation in Social Movement Coalitions: Lobbying for Peace in the 1980s. Berkeley Journal of Sociology, 38, 157-183.

Kendall, J. (Ed.). (2009). Handbook on Third Sector Policy in Europe: Multi-level Processes and Organized Civil Society. Cheltenham: Edward Elgar.

Klandermans, B. (1993). A Theoretical Framework for Comparisons of Social Movement Participation. Sociological Forum, 8(3), 383-402.

Klandermans, B., \& Oegema, D. (1987). Potentials, Networks, Motivations, and Barriers: Steps Towards Participation in Social Movements. American Sociological Review, 52(4), 519-531.

Komter, A. E. (2005). Social Solidarity and the Gift. Cambridge: Cambridge University Press.

Kousis, M. (2017). Alternative Forms of Resilience Confronting Hard Economic Times. A South European Perspective. Partecipazione e conflitto, 10(1), 119-135.

Kousis, M., \& Paschou, M. (2017). Alternative Forms of Resilience. A Typology of Approaches for the Study of Citizen Collective Responses in Hard Economic Times. Partecipazione e Conflitto, 10(1), 136-168.

Kousis, M., Kalogeraki, S., \& Cristancho, C. (2018). Alternative Action Organizations During Hard Economic Times: A Comparative European Perspective. American Behavioral Scientist, 62(6), 733-738.

Kousis, M., Loukakis, A., Paschou, M., \& Lahusen, C. (2020). Waves of Transnational Solidarity Organisations in Times of Crises: Actions, Obstacles and Opportunities in Europe. In C. Lahusen (Ed.), Citizens' Solidarity in Europe. Civic Engagement and Public Discourse in Times of Crisis (pp. 55-84). Cheltenham: Edward Elgar.

Kriesi, H. (2016). Mobilization and Protest in the Age of Austerity. In M. Ancelovici, P. Dufour, \& H. Nez (Eds.), Street Politics in the Age of Austerity: From the Indignados to Occupy (pp. 67-90). Amsterdam: Amsterdam University Press. 
Lahusen, C. (Ed.). (2020). Citizens' Solidarity in Europe. Civic Engagement and Public Discourse in Times of Crises. Cheltenham: Edward Elgar.

Lahusen, C., \& Grasso, M. T. (Eds.). (2018). Solidarity in Europe. Citizens' Responses in Times of Crisis. Cham: Palgrave/Macmillan.

Lahusen, C., Kousis, M., Zschache, U., \& Loukakis, A. (2018). European Solidarity in Times of Crisis: Comparing Transnational Activism of Civic Organisations in Germany and Greece. Österreichische Zeitschrift für Soziologie, 43(1), 173-197.

MacIndoe, H. (2014). How Competition and Specialization Shape Nonprofit Engagement in Policy Advocacy. Nonprofit Policy Forum, 5(2), 307-333.

McAdam, D., McCarthy, J. D., \& Zald, M. N. (1996). Comparative Perspectives on Social Movements. Political Opportunities, Mobilizing Structures, and Cultural Framings. Cambridge: Cambridge University Press.

McCallum, J. K. (2013). Global Unions, Local Power: The New Spirit of Transnational Labour Organizing. Ithaca: ILR/Cornell University Press.

McCarthy, J. D., \& Zald, M. N. (1977). Resource Mobilization and Social Movements: A Partial Theory. American Journal of Sociology, 82, 1212-1214. Minkoff, D. C. (2002). The Emergence of Hybrid Organizational Forms: Combining Identity-Based Service Provision and Political Action. Nonprofit and Voluntary Sector Quarterly, 31(3), 377-401.

Minkoff, D. C., \& Powell, W. W. (2006). Nonprofit Mission: Constancy, Responsiveness, or Deflection? In W. W. Powell \& R. Steinberg (Eds.), The Nonprofit Sector: A Research Handbook (2nd ed., pp. 591-609). Yale: Yale University Press.

Monforte, P. (2014). Europeanizing Contention: The Protest Against 'Fortress Europe' in France and Germany. New York: Berghahn Books.

Passy, F. (2001). Political Altruism and the Solidarity Movement: An Introduction. In M. Giugni \& F. Passy (Eds.), Political Altruism? Solidarity Movements in International Perspective (pp. 3-25). Boston: Rowman \& Littlefield.

Pope, S., Bromley, P., Lim, A., \& Meyer, J. W. (2018). The Pyramid of Nonprofit Responsibility: The Institutionalization of Organizational Responsibility Across Sectors. Voluntas, 29, 1300-1314.

Powell, W. W., \& DiMaggio, P. J. (Eds.). (1992). The New Institutionalism in Organizational Analysis. Chicago: University of Chicago Press.

Putnam, R. D. (2000). Bowling Alone: The Collapse and Revival of American Community. New York: Simon \& Schuster. 
Roulston, K. (2014). Analysing Interviews. In U. Flick (Ed.), The Sage Handbook of Qualitative Data Analysis (pp. 297-312). London: Sage.

Rucht, D. (1990). The Strategies and Action Repertoires of New Movements. In R. Dalton \& M. Kuechler (Eds.), Challenging the Political Order: New Social and Political Movements in Western Democracies (pp. 156-175). Cambridge: Polity Press.

Salamon, L. M., \& Sokolowski, S. W. (2016). Beyond Nonprofits: Re-conceptualizing the Third Sector. Voluntas, 27(4), 1515-1545.

Scholz, S. J. (2008). Political Solidarity. Penn State University Press: University Park.

Schroeder, D. A., Penner, L. A., Dovidio, J. F., \& Piliavin, J. A. (1995). The Psychology of Helping and Altruism: Problems and Puzzles. New York: McGraw-Hill.

Scipes, K. (Ed.). (2016). Building Global Labor Solidarity in a Time of Accelerating Globalization. Chicago: Haymarket Books.

Skitka, L. J., \& Tetlock, P. E. (1993). Providing Public Assistance: Cognitive and Motivational Processes Underlying Liberal and Conservative Policy Preferences. Journal of Personality and Social Psychology, 65(6), 1205-1223.

Smismans, S. (2006). Civil Society and Legitimate European Governance. Cheltenham: Edward Elgar.

Smith, J. (1997). Transnational Social Movements and Global Politics: Solidarity Beyond the State. Syracuse: Syracuse University Press.

Smith, J., \& Johnston, H. (2002). Globalization and Resistance. The Transnational Dimensions of Social Movements. Lanham: Rowman \& Littlefield.

Smith, C., \& Sorrell, K. (2014). On social Solidarity. In V. Jeffries (Ed.), The Palgrave Handbook on Altruism, Morality, and Social Solidarity. Formulating a Field of Study (pp. 219-248). New York: Palgrave Macmillan.

Soldatic, K., \& Grech, S. (2014). Transnationalising Disability Studies: Rights, Justice and Impairment. Disability Studies Quarterly, 34(2). Retrieved from: https://dsq-sds.org/article/view/4249/3588

Soule, S. A., \& King, B. G. (2008). Competition and Resource Partitioning in Three Social Movement Industries. American Journal of Sociology, 113(6), $1568-1610$.

Stjerno, S. (2012). Solidarity in Europe. The History of an Idea. Cambridge: Cambridge University Press.

Strauss, A., \& Corbin, J. (1990). Basics of Qualitative Research. Grounded Theory Procedures and Techniques. Newbury Park: Sage. 
Tarrow, S. (1996). States and Opportunities: The Political Structuring of Social Movements. In D. McAdam, J. D. McCarthy, \& M. N. Zald (Eds.), Comparative Perspectives on Social Movements. Political Opportunities, Mobilizing Structures, and Cultural Framings (pp. 41-61). Cambridge: Cambridge University Press.

Tarrow, S., \& McAdam, D. (2005). Scale Shift in Transnational Contention' in Transnational Protest and Global Activism. In D. della Porta \& S. Tarrow (Eds.), Transnational Protest and Global Activism (pp. 121-148). Lanham: Rowman \& Littlefield.

Tilly, C. (1984). Social Movements and National Politics. In C. Bright \&

S. Harding (Eds.), Statemaking and Social Movements: Essays in History and Theory (pp. 297-317). Ann Arbor: University of Michigan Press.

Tilly, C. (2004). Social Movements, 1768-2004. Boulder: Paradigm Publishers. TransSOL. (2016). Work Package 2 Integrated Report on Reflective Forms of Transnational Solidarity. Retrieved from https://blogs.uni-siegen.de/transsol/ files/2016/12/Integrated-Report-on-Reflective-Forms-of-TransnationalSolidarity.pdf

Traugott, M. (Ed.). (1995). Repertoires and Cycles of Collective Action. Durham: Duke University Press.

Uba, K., \& Kousis, M. (2018). Constituency Groups of Alternative Action

Organizations During Hard Times: A Comparison at the Solidarity Orientation and Country Levels. American Behavioral Scientist, 62(6), 816-836.

van Laer, J., \& van Aelst, P. (2010). Internet and Social Movement Action

Repertoires. Information, Communication \& Society, 13(8), 1146-1171. van Oorschot, W. (2000). Who Should Get What, and Why? On Deservingness

Criteria and the Conditionality of Solidarity among the Public. Policy \& Politics, 28(1), 33-48.

van Oorschot, W., Arts, W., \& Gelissen, J. (2006). Social Capital in Europe. Measurement and Social and Regional Distribution of a Multifaceted Phenomenon. Acta Sociologica, XLIX, 149-167.

Verschraegen, G., \& Vandevoordt, R. (2019). The European Refugee Controversy: Civil Solidarity, Cultural Imaginaries and Political Change. Social Inclusion, 7(2), 48-52.

Wada, T. (2016). Rigidity and Flexibility of Repertoires of Contention. Mobilization, 21(4), 449-468.

Zald, M.N., \& McCarthy, J.D. (1979). Social Movement Industries: Competition and Cooperation among Movement Organizations. Ann Arbor, Michigan: Center for Research on - Working Paper Series (CRSO) Working Paper \#201. 
Zamponi, L. (2019). Direct Social Action, Welfare Retrenchment and Political Identities. Coping with the Crisis and Pursuing Change in Italy. Partecipazione e conflitto, 12(2), 382-409.

Zschache, U., Theiss, M., \& Paschou, M. (2020, forthcoming). What Is Solidarity About? Views of Transnational Solidarity Activists in Germany, Poland and Greece. Sociological Research Online, Special Issue: Transnational Solidarity Organizations in Times of Crises: Comparative European Perspectives.

Open Access This chapter is licensed under the terms of the Creative Commons Attribution 4.0 International License (http://creativecommons.org/licenses/ by/4.0/), which permits use, sharing, adaptation, distribution and reproduction in any medium or format, as long as you give appropriate credit to the original author(s) and the source, provide a link to the Creative Commons licence and indicate if changes were made.

The images or other third party material in this chapter are included in the chapter's Creative Commons licence, unless indicated otherwise in a credit line to the material. If material is not included in the chapter's Creative Commons licence and your intended use is not permitted by statutory regulation or exceeds the permitted use, you will need to obtain permission directly from the copyright holder.

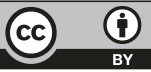

